\title{
Umami Responses in Mouse Taste Cells Indicate More than One Receptor
}

\author{
Yutaka Maruyama, ${ }^{1}$ Elizabeth Pereira, ${ }^{1}$ Robert F. Margolskee, ${ }^{3}$ Nirupa Chaudhari, ${ }^{1,2}$ and Stephen D. Roper ${ }^{1,2}$ \\ ${ }^{1}$ Department of Physiology and Biophysics and ${ }^{2}$ Program in Neuroscience, University of Miami Miller School of Medicine, Miami, Florida 33136, and \\ ${ }^{3}$ Department of Neuroscience, Mount Sinai School of Medicine, New York, New York 10029
}

\begin{abstract}
A number of gustatory receptors have been proposed to underlie umami, the taste of L-glutamate, and certain other amino acids and nucleotides. However, the response profiles of these cloned receptors have not been validated against responses recorded from taste receptor cells that are the native detectors of umami taste. We investigated umami taste responses in mouse circumvallate taste buds in an intact slice preparation, using confocal calcium imaging. Approximately $5 \%$ of taste cells selectively responded to L-glutamate when it was focally applied to the apical chemosensitive tips of receptor cells. The concentration-response range for L-glutamate fell approximately within the physiologically relevant range for taste behavior in mice, namely $10 \mathrm{~mm}$ and above. Inosine monophosphate enhanced taste cell responses to L-glutamate, a characteristic feature of umami taste. Using pharmacological agents, ion substitution, and immunostaining, we showed that intracellular pathways downstream of receptor activation involve phospholipase $\mathrm{C} \beta 2$. Each of the above features matches those predicted by studies of cloned and expressed receptors. However, the ligand specificity of each of the proposed umami receptors [taste metabotropic glutamate receptor 4 , truncated metabotropic glutamate receptor 1 , or taste receptor 1 (T1R1) and T1R3 dimers], taken alone, did not appear to explain the taste responses observed in mouse taste cells. Furthermore, umami responses were still observed in mutant mice lacking T1R3. A full explanation of umami taste transduction may involve novel combinations of the proposed receptors and/or as-yet-undiscovered taste receptors.
\end{abstract}

Key words: taste; receptor; signal transduction; glutamate; phospholipase; imaging; umami

\section{Introduction}

The perceived taste of glutamate, called umami, is believed to be distinct from sour, salty, sweet, and bitter (Lindemann et al., 2002). A characteristic feature of umami taste is its potentiation by purine (inosine, guanosine) nucleotide- $5^{\prime}$-monophosphates, which also elicit an umami flavor on their own. The prototypic umami tastant monosodium glutamate (MSG) stimulates food intake in humans and other mammals and is widely used as a flavor enhancer in many cuisines in processed foods and in animal feed.

At least three G-protein-coupled receptors (GPCRs) have been proposed as taste receptors for glutamate. A taste-specific variant of a metabotropic glutamate receptor, taste-mGluR4, is expressed in rat taste buds from the posterior tongue (Chaudhari et al., 1996, 2000; Yang et al., 1999). When expressed in transfected cells, taste-mGluR4 responds to MSG and L-2-amino-4phosphonobutyrate (L-AP-4) at taste-effective concentrations (Chaudhari et al., 2000). A heterodimer of two taste-specific GPCRs, taste receptor 1 (T1R1) + T1R3, when expressed in het-

Received 0ct. 11, 2005; revised Jan. 10, 2006; accepted Jan. 11, 2006.

This work was supported by National Institutes of Health-National Institute on Deafness and Other Communication Disorders Grants R01 003155 (R.F.M.), R01 006308 (N.C.), and R01 000374 (S.D.R.) and the International Glutamate Technical Committee. We thank Dr. Dianqing Wu (University of Connecticut Health Center, Farmington, (T) for providing mutant mice lacking $\mathrm{PLC} \beta 2$.

Correspondence should be addressed to S. D. Roper, Department of Physiology and Biophysics, University of Miami Miller School of Medicine, 1600 NW 10th Avenue, Miami, FL 33136. E-mail: roper@miami.edu. D01:10.1523/JNEUROSCI.4329-05.2006

Copyright $\odot 2006$ Society for Neuroscience $\quad$ 0270-6474/06/262227-08\$15.00/0 erologous cells, also confers the ability to respond to glutamate and many non-umami amino acids. Additional receptors proposed for umami include a truncated mGluR1 (San Gabriel et al., 2005). Although these cloned receptors all appear to respond to umami stimuli when expressed in culture, which ones underlie native responses remains equivocal. Specifically, in contrast to behavioral responses, T1R1 + T1R3 responds minimally to glutamate alone and instead requires a mix of glutamate and nucleotide for activation (Nelson et al., 2002). Conversely, tastemGluR4 responds well to glutamate alone, but its response is unaltered by nucleotides (Chaudhari et al., 2000). Even genetic ablation studies of $\mathrm{T} 1 \mathrm{R}$ receptors in mice have yielded conflicting data on umami taste (Damak et al., 2003; Zhao et al., 2003). Hence, the role of umami taste receptors has been inferred from indirect studies based on heterologous expression, afferent nerve recordings, and taste behavior.

Investigators have attempted to define umami receptor mechanisms using patch-clamp recordings or $\mathrm{Ca}^{2+}$ imaging on isolated taste buds with bath application of stimuli (Hayashi et al., 1996; Bigiani et al., 1997; Lin and Kinnamon, 1999; Lin et al., 2003). However, those findings are inconclusive because of the inability to confine chemical stimuli strictly to the apical, chemosensory tips of taste cells. The results are confounded by activating basolateral (nontaste) glutamate receptors and channels (Caicedo et al., 2000). In short, whether and how any of the proposed taste receptors can fully explain umami responses in native tissues (i.e., taste buds) has not yet been convincingly established. 
There is general concurrence regarding glutamate taste transduction downstream of the umami taste receptors. Transduction for umami has been shown to involve the G-protein $\mathrm{G} \alpha$ gustducin (He et al., 2004) and cAMP modulation (Abaffy et al., 2003). Knock-out (KO) of the phospholipase C (PLC) isoform expressed in taste cells, PLC $\beta 2$, leads to a striking deficit of afferent nerve response and taste behavior to umami stimuli. Collectively, umami transduction is believed to involve a GPCRtriggered modulation of $\left[\mathrm{Ca}^{2+}\right]_{\mathrm{i}}$ and cAMP in taste sensory cells and subsequent release of transmitter to excite gustatory afferent fibers.

In the present study, we used a semi-intact tissue preparation in which it is possible to apply glutamate and other taste stimuli focally restricted to the apical chemosensitive tips of taste-bud cells and measure individual cellular responses with excellent time and spatial resolution. We show that responses to umami and amino acid tastants, at least in the posterior tongue, are surprisingly heterogeneous. The results suggest that more than a single receptor underlie umami detection in mouse taste buds.

\section{Materials and Methods}

Tissue preparation and functional imaging. All experimental procedures were approved by the University of Miami Care and Use Committee. Animals were killed by exposure to $\mathrm{CO}_{2}$, followed by cervical dislocation. Tongues were removed and immersed in cold $\left(4^{\circ} \mathrm{C}\right)$ Tyrode's solution. We obtained lingual slices containing the vallate papilla from adult C57BL/6 mice ( $\geq 8$ weeks old) and injected a calcium indicator dye into taste cells following similar procedures described by Caicedo et al. (2000, 2002). Briefly, the fluorescent $\mathrm{Ca}^{2+}$ indicator dye Calcium Green-1 dextran (CaGD) ( $1 \mathrm{~mm}$ in $\mathrm{H}_{2} \mathrm{O}$, molecular weight, $\mathrm{kDa}$; Invitrogen, Carlsbad, CA) was injected iontophoretically through a large-diameter-tip (40 $\mu \mathrm{m})$ glass micropipette into the crypt surrounding the vallate papilla $(-3.5 \mu \mathrm{A}$ square pulses, $10 \mathrm{~min})$. The CaGD-loaded tissue was sliced at $100 \mu \mathrm{m}$ with a vibratome (VT1000S; Leica, Nussloch, Germany). Slices containing vallate taste buds were mounted on a glass coverslip coated with Cell-Tak (BD Biosciences, Franklin Lakes, NJ), put in a recording chamber, and superfused with Tyrode's solution $\left(30^{\circ} \mathrm{C}\right)$ at rate of $2 \mathrm{ml} /$ $\mathrm{min}$. Single glass micropipettes ( $2 \mu \mathrm{m}$ tip diameter) were used to deliver taste stimuli directly for apical stimulation of a selected taste bud. Stimuli were ejected for $1 \mathrm{~s}$ with air pressure (1.5 psi) (PicoSpritzer; General Valve, Fairfield, NJ). Different pipettes were mounted for each different taste stimulus. All stimulus solutions contained $2 \mu \mathrm{m}$ fluorescein to monitor stimulus application, duration, and concentration.

CaGD-loaded taste cells were viewed with a scanning laser confocal microscope using an argon laser (Fluoview; Olympus Optical, Melville, $\mathrm{NY}$ ). Images were captured at $1.1 \mathrm{~s}$ intervals unless otherwise noted. Fluorometric signals are expressed as relative fluorescence change: $\Delta F /$ $F=\left(F-F_{0}\right) / F_{0}$, where $F_{0}$ denotes the resting fluorescence level corrected for any bleaching that occurred during the recording. Using $\Delta F / F$ corrects for variations of baseline fluorescence, cell thickness, total dye concentration, and illumination (Helmchen, 2000). Peak $\Delta F / F$ constituted the response amplitude for statistical quantification. Taste buds could be stimulated repeatedly with a variety of taste stimuli, and viable responses could be collected from taste cells for up to $5 \mathrm{~h}$.

Data analysis. Statistical analyses of significance (paired Student's $t$ test, ANOVA with appropriate post hoc tests, or Fisher's exact test, one tailed) were applied to peak $\Delta F / F$ to determine whether the changes in the response amplitudes to a given treatment were significant.

Reagents and solutions. L-AP-4 was purchased from Tocris Bioscience (Ellisville, MO). All other chemicals, including monopotassium Lglutamate (MPG) and inosine $5^{\prime}$-monophosphate (IMP), were purchased from Sigma (St. Louis, MO). All tastants were freshly dissolved in Tyrode's solution for each experiment. The standard medium consisted of Tyrode's solution with the following composition (in mM): $130 \mathrm{NaCl}$, $5 \mathrm{KCl}, 8 \mathrm{CaCl}_{2}, 1 \mathrm{MgCl}_{2}, 10 \mathrm{HEPES}, 10$ glucose, 10 sodium pyruvate, and $5 \mathrm{NaHCO}_{3}$, pH 7.3 (318-323 mOsm). For Ca ${ }^{2+}$-free Tyrode's solution, $\mathrm{CaCl}_{2}$ was removed, and $0.2 \mathrm{~mm}$ EGTA was added to the above compo-

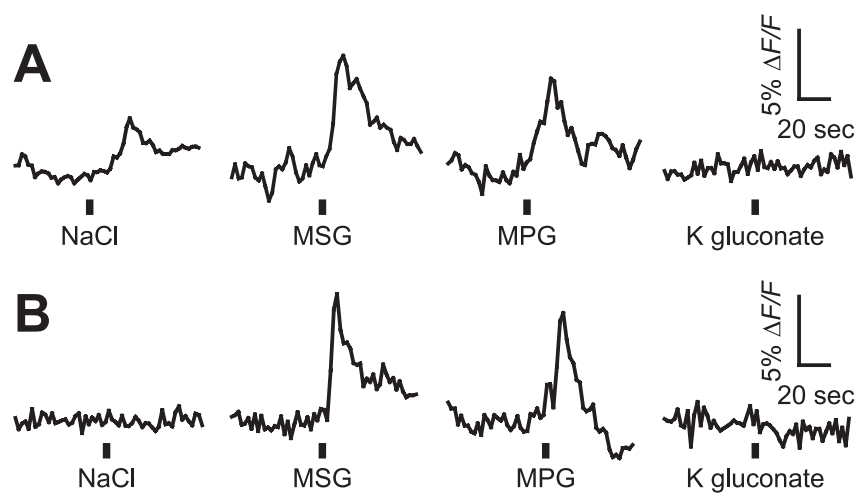

Figure 1. Taste cell responses $\left(\Delta \mathrm{Ca}^{2+}\right)$ evoked by umami and salty taste stimuli, recorded in a slice preparation of the mouse circumvallate papilla. Taste cells were stimulated sequentially with four salt compounds, all at $500 \mathrm{~mm}$. A, Sequential responses of one taste cell. $\mathrm{NaCl}$, MSG, MPG, and potassium gluconate were applied focally and transiently onto the chemosensitive apical tip of taste buds, as shown by short bars below the traces. The $\mathrm{Na}^{+}$(i.e., $\mathrm{NaCl}, \mathrm{MSG}$ traces) and the glutamate (i.e., MSG, MPG traces) moieties both evoked responses in this cell. $\boldsymbol{B}$, The same sequence of taste stimuli, applied to another taste cell, produced $\mathrm{Ca}^{2+}$ responses from the glutamate moiety alone.

sition. Stock solutions of phospholipase C inhibitor, U73122 (1[6[[(17 $\beta)$-3-methoxyestra-1,3,5(10)-trien-17-yl] amino $]$ hexyl $]-1 \mathrm{H}$ pyrrole-2,5-dione), and endoplasmic reticulum $\mathrm{Ca}^{2+}$-ATPase inhibitor, thapsigargin, were dissolved in DMSO at 10 and $1 \mathrm{~mm}$, respectively, and stored at $-20^{\circ} \mathrm{C}$.

Immunostaining. To examine colocalization of PLC $\beta 2$-expressed cells and MPG-responsive cells, we immunostained lingual tissue slices after physiological recordings. Lingual slices from which we recorded $\mathrm{Ca}^{2+}$ responses were processed for immunohistochemistry using antibodies against PLC $\beta 2$ (rabbit polyclonal; Santa Cruz Biotechnology, Santa Cruz, CA). Tissue slices were fixed with $4 \%$ paraformaldehyde in PBS for $20 \mathrm{~min}$ at room temperature. Slices were rinsed three times in PBS and blocked with PBS containing $1 \%$ goat serum, $3 \%$ bovine serum albumin, and $0.3 \%$ Triton $\mathrm{X}-100$ for $2 \mathrm{~h}$. Slices were incubated in primary antibody (1:1000) for $3 \mathrm{~d}$ at $4^{\circ} \mathrm{C}$. Thereafter, slices were washed three times in PBS, incubated for $3 \mathrm{~d}$ in Alexa Fluor 594-conjugated secondary antibodies (1:500; Invitrogen), and then washed again three times in PBS.

To relocate cells from which recordings were taken, fixed and immunostained slices were imaged by laser scanning confocal microscope using argon (488 nm) and krypton (568 nm) lasers and emission filters for CaGD and Alexa Fluor 594. Dual-fluorescence images were matched with those obtained during the $\mathrm{Ca}^{2+}$ imaging recordings from the living tissue to relocate specific cells.

\section{Results}

\section{Calcium responses to focally applied glutamate represent umami taste}

L-Glutamate might be expected to elicit a variety of responses in taste cells because this amino acid is an umami taste stimulus, serves a number of metabolic roles, and may also be a synaptic transmitter in taste buds. To limit glutamate responses to those associated proximately with taste, we used a semi-intact lingual slice preparation, focally applied glutamate to the apical chemosensory tips of taste receptor cells, and imaged intracellular $\left[\mathrm{Ca}^{2+}\right]$ changes in taste cells with confocal scanning microscopy (Caicedo et al., 2000; Richter et al., 2003). Focal application of MSG $(500 \mathrm{~mm})$ produced calcium responses $\left(\Delta\left[\mathrm{Ca}^{2+}\right]_{\mathrm{i}}\right)$ in a fraction of taste cells (Fig. $1 A, B$ ). Some, but not all, MSGresponsive cells also responded to focally applied $\mathrm{NaCl}(500 \mathrm{~mm})$ because $\mathrm{Na}^{+}$is itself a taste stimulus (i.e., salty) and elicits taste responses in taste cells (Fig. 1A) (Caicedo et al., 2002). In an attempt to identify a chemical stimulus that would selectively stimulate glutamate taste receptors without confounding salty 


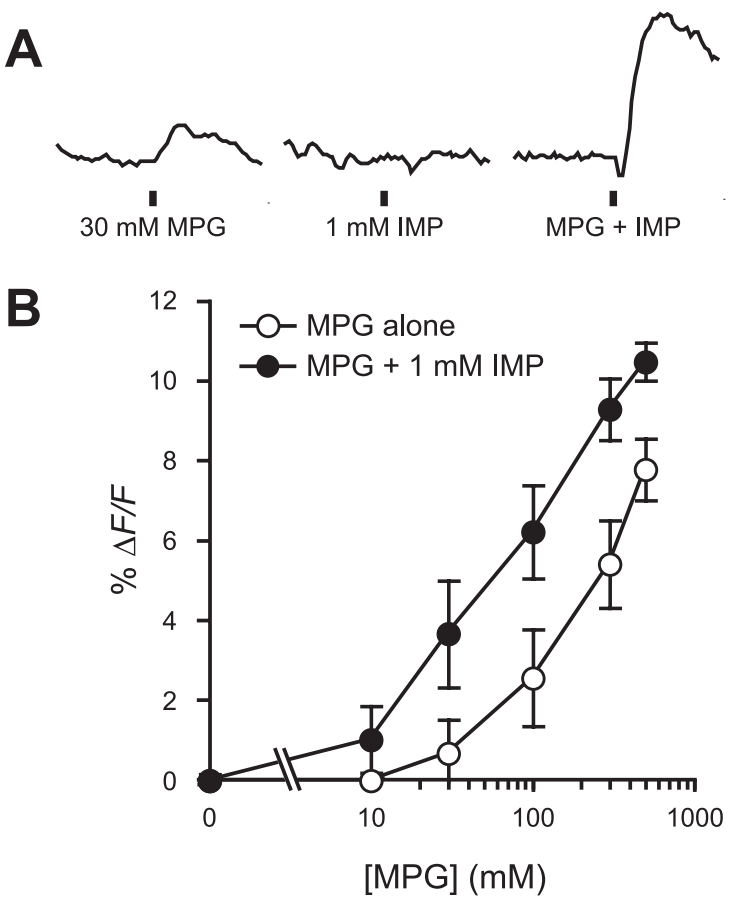

Figure 2. Glutamate responses are enhanced by coapplication of IMP, consistent with umami taste stimulation. $\boldsymbol{A}$, Responses evoked by MPG $(30 \mathrm{~mm})$ were enhanced by coapplication of IMP (1 mM). IMP alone did not induce a detectable $\mathrm{Ca}^{2+}$ response (middle trace). $\boldsymbol{B}$, Concentration-response relationship for glutamate in the presence (filled circles) or absence (open circles) of $1 \mathrm{~mm} \mathrm{IMP}$ (means $\pm \mathrm{SE} ; n=4$ cells)

responses, we compared responses evoked by focal application of MSG, $\mathrm{NaCl}, \mathrm{MPG}$, potassium gluconate, and $\mathrm{KCl}$. The results indicated that MPG reliably evoked taste responses to the glutamate moiety and were least likely to be confounded with salty (i.e., $\mathrm{Na}^{+}$) or other taste responses (Fig. 1). Focal stimulation with $\mathrm{KCl}$ (data not shown) or with potassium gluconate did not elicit a change of $\left[\mathrm{Ca}^{2+}\right]_{\mathrm{i}}$, further validating the taste specificity of the glutamate responses. [Gluconate does not itself appear to elicit a taste (Delwiche et al., 1999).] Furthermore, whereas focal $\mathrm{KCl}$ and potassium gluconate did not elicit a response in MPGresponsive cells, $\mathrm{NH}_{4}$ glutamate did (data not shown). Thus, all additional experiments were conducted using MPG as an umami stimulus. (We did not distinguish between cells that responded only to glutamate and those that responded to glutamate and $\mathrm{Na}^{+}$.) We note that MPG has also been used in experiments using nerve recordings and behavioral assays and has been shown to be an effective umami tastant (Sako et al., 2003).

Focally applied MPG (500 mM) evoked transient $\left[\mathrm{Ca}^{2+}\right]_{\mathrm{i}}$ increases in $4.2 \%$ of taste cells in the circumvallate papilla ( 34 of 804 cells obtained from 28 mice). This fraction is lower than the $11 \%$ of cells reported previously to respond to monosodium glutamate (Caicedo et al., 2002). However, that previous study stimulated taste cells with MSG and thus could not selectively distinguish umami versus salty taste responses. The mean amplitude of $\mathrm{Ca}^{2+}$ responses $(\Delta F / F)$ evoked by $500 \mathrm{mM} \mathrm{MPG}$ was $7.4 \pm 1.5 \%$ (mean \pm SE; $n=34$ cells).

We determined concentration-response relationships for MPG and found the threshold value at or near $10 \mathrm{~mm}$ (Fig. 2B, open circles). This value is similar to threshold concentrations of glutamate required for afferent nerve responses or behavioral assays (Yamamoto et al., 1991; Bachmanov et al., 2000; Inoue et al., 2004). We could not apply MPG at concentrations much over $500 \mathrm{~mm}$ and did not establish a saturating dose for the concen-
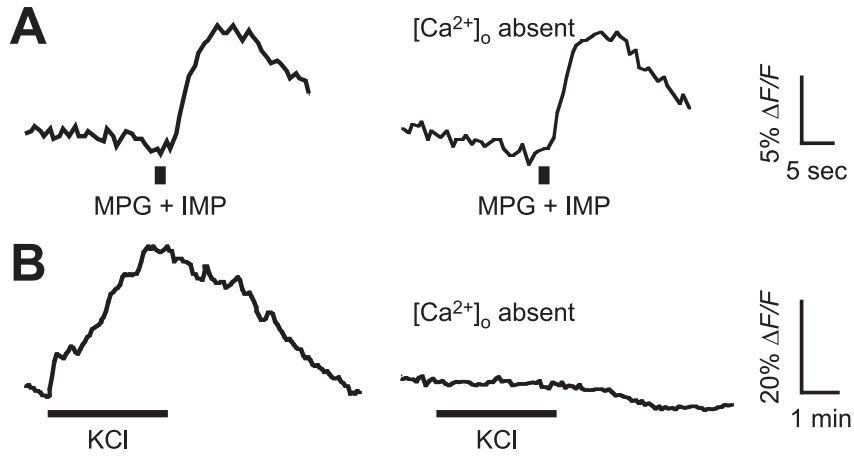

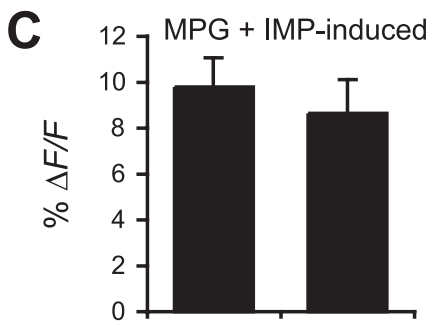

$(+)$
$(-)$

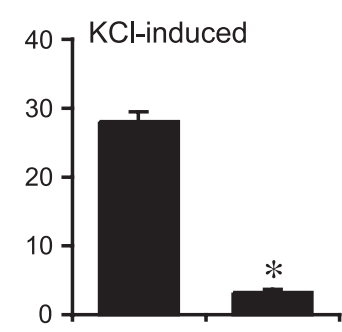

$(+)$
$(-)$
$\left[\mathrm{Ca}^{2+}\right]_{0}$

Figure 3. Taste responses elicited by glutamate are unaffected by removing extracellular $\mathrm{Ca}^{2+}$. A, MPG (200 mM) plus IMP (1 mM) was focally applied in medium containing $\mathrm{Ca}^{2+}$ (left trace) or in the absence of $\mathrm{Ca}^{2+}$ ( $\mathrm{Ca}$-free medium with $0.2 \mathrm{~mm}$ EGTA; right trace). $\boldsymbol{B}$, Responses elicited by depolarization (bath-applied $\mathrm{KCl}, 50 \mathrm{~mm}$ ) and influx of $\mathrm{Ca}^{2+}$ through voltagedependent $\mathrm{Ca}^{2+}$ channels were abolished in the absence of $\left[\mathrm{Ca}^{2+}\right]_{0}$. $\mathrm{C}$, Mean amplitudes of $\mathrm{MPG}$-induced responses in the presence or absence of $\left[\mathrm{Ca}^{2+}\right]_{0}$ (mean $\left.\pm \mathrm{SE} ;{ }^{*} p \leq 0.001\right)$.

tration-response relationships. Thus, it was not possible to derive $\mathrm{EC}_{50}$ values (Fig. 2). Importantly, applying concentrations of glutamate $(>30 \mathrm{~mm})$ did not recruit $\mathrm{Ca}^{2+}$ responses in additional taste cells. This suggests that the $\mathrm{Ca}^{2+}$ responses we recorded did not represent nonspecific activation of taste-bud cells and instead reflected selective stimulation of a specific subpopulation of glutamate-responsive taste receptor cells.

Behavioral and afferent nerve responses to glutamate are synergistically enhanced by the presence of $5^{\prime}$-ribonucleotides, a characteristic feature of umami taste (Kuninaka, 1960). Thus, we tested whether glutamate-induced $\mathrm{Ca}^{2+}$ responses were altered by IMP, as expected for umami signals. MPG $(10-500 \mathrm{mM})$ was focally applied with or without $1 \mathrm{~mm}$ IMP to the apical taste pore of circumvallate taste buds in slices. Glutamate-induced $\left[\mathrm{Ca}^{2+}\right]_{\mathrm{i}}$ responses were enhanced in the presence of IMP, and the concentration-response relationship appeared to be left-shifted $\sim 1 / 2$ $\log$ unit (Fig. 2A,B). (Without data for saturating responses, we could not establish whether this shift represented synergy, per se, between IMP and MPG.) When we applied $1 \mathrm{~mm}$ IMP alone, it did not induce $\left[\mathrm{Ca}^{2+}\right]_{\mathrm{i}}$ responses.

\section{Responses to umami stimuli represent phospholipase-} induced $\mathrm{Ca}^{2+}$ release

We next investigated the $\mathrm{Ca}^{2+}$-mobilizing pathway activated by umami stimuli in taste cells. First, we examined responses in the acute absence of extracellular $\mathrm{Ca}^{2+}$ by bathing slices in a $\mathrm{Ca}^{2+}$. free Tyrode's solution (with EGTA) 2 min before focal glutamate stimulation. As shown in Figure 3, $A$ and $C$, responses evoked by monopotassium glutamate (plus IMP) were not significantly changed relative to those in the presence of extracellular $\mathrm{Ca}^{2+}$ (control, $\Delta F / F=9.8 \pm 1.3 \% ; \mathrm{Ca}^{2+}$-free, $\Delta F / F=8.7 \pm 1.5 \% ; n=$ 9). In contrast, depolarization-evoked $\mathrm{Ca}^{2+}$ responses, elicited 
by perfusing the slice with $50 \mathrm{~mm} \mathrm{KCl}$ [which allows $\mathrm{Ca}^{2+}$ influx through voltage-gated cation channels (Richter et al., 2004)] were nearly completely abolished in the absence of extracellular $\mathrm{Ca}^{2+}$ under parallel treatments (control, $\Delta F /$ $F=28.1 \pm 1.5 \% ; \mathrm{Ca}^{2+}$-free, $\Delta F / F=3.2 \pm$ $0.5 \% ; n=12 ; p<0.001$ ) (Fig. $3 B, C$ ). These results are consistent with umami taste transduction involving release of intracellular $\mathrm{Ca}^{2+}$, not $\mathrm{Ca}^{2+}$ influx.

To test directly whether glutamateevoked $\mathrm{Ca}^{2+}$ responses originated from intracellular stores, we depleted $\mathrm{Ca}^{2+}$ stores with thapsigargin ( $1 \mu \mathrm{M}, 20 \mathrm{~min})$, a selective inhibitor of endoplasmic reticulum $\mathrm{Ca}^{2+}$-ATPase (Thastrup et al., 1990). After thapsigargin treatment, $\mathrm{Ca}^{2+}$ responses evoked by MPG (plus IMP) were diminished by $73 \%$ (control, $\Delta F / F=$ $10.7 \pm 1.5 \%$; thapsigargin, $\Delta F / F=2.3 \pm$ $0.9 \% ; n=4 ; p \cong 0.01$ ) (Fig. $4 A, C$ ). In contrast, depolarization ( $\mathrm{KCl})$-induced responses were not affected by thapsigargin (control, $\Delta F / F=28.8 \pm 2.0 \%$; thapsigargin, $\Delta F / F=31.7 \pm 1.5 \% ; n=8$ ) (Fig. $4 B, C)$. These data strongly support the notion that glutamate taste mechanisms involve intracellular $\mathrm{Ca}^{2+}$ release.

Many sweet, bitter, and umami stimuli are believed to trigger the release of stored $\mathrm{Ca}^{2+}$ by activating PLC $\beta 2$ (Rossler et al., 1998; Huang et al., 1999; Ogura and Kinnamon, 1999; Zhang et al., 2003). To directly test whether umami-elicited $\mathrm{Ca}^{2+}$ responses stem from PLC activation, we used a nonselective PLC inhibitor, U73122 (Bleasdale et al., 1990; Thompson et al., 1991; Salari et al., 1993). After incubation with $10 \mu \mathrm{M}$ U73122 for $15 \mathrm{~min}$, responses elicited by MPG (plus IMP) were inhibited $74 \%$ (control, $\Delta F / F=10.8 \pm 0.8 \%$; $\mathrm{U} 73122, \Delta F / F=2.8 \pm 1.7 \% ; n=4 ; p \cong$ 0.003 ) (Fig. $4 D, F$ ). In contrast, depolarization $(\mathrm{KCl})$-induced responses were not significantly altered by treatment with U73122 (control, $\Delta F / F=32.7 \pm 2.3 \%$; U73122, $\Delta F / F=29.3 \pm 3.2 \% ; n=6$ ) (Fig. $4 E, F)$.

Last, to correlate umami taste responses with the presence of PLC $\beta 2$ on an individual cell basis, lingual slices from which successful recordings of MPG (plus IMP) responses were taken were immunostained for the presence of PLC $\beta 2$. After fixation and immunostaining, recorded cells were relocated by their CaGD dye fluorescence (which remained throughout the immunostaining) and by their position within the lingual slice. MPGresponsive cells were immunopositive for PLC $\beta 2$ (Fig. 5), confirming the direct and immediate association between umami taste mechanisms and the presence of PLC $\beta 2$. The specificity of
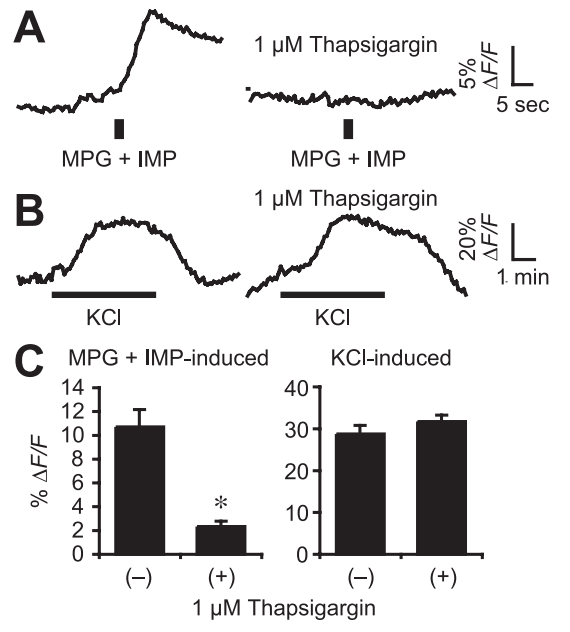

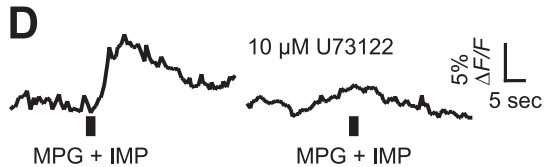

E
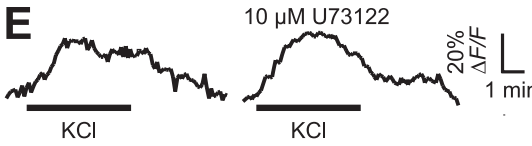

F $M P G+I M P$-induced

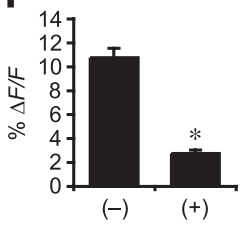

$10 \mu \mathrm{M} U 73122$

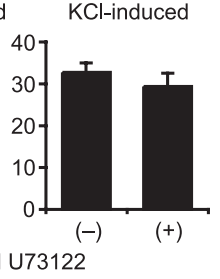

Figure 4. $\quad \mathrm{Ca}^{2+}$ response elicited by glutamate involves intracellular $\mathrm{Ca}^{2+}$ stores and phospholipase $C$. $A$, Responses evoked by MPG ( $200 \mathrm{~mm}$ ) plus IMP ( $1 \mathrm{~mm}$; left) were blocked by thapsigargin ( $1 \mu \mathrm{m}$; right). B, Responses evoked by depolarization ( $50 \mathrm{~mm}$ $\mathrm{KCl}$ ) were unaffected by thapsigargin. $C$, Mean amplitudes of the responses in the presence or absence of thapsigargin (mean \pm $\left.\mathrm{SE}_{;}{ }^{*} p \cong 0.01\right)$. D. Responses to MPG plus IMP in another cell were inhibited by U73122 (10 $\mu \mathrm{M}$; right). $\boldsymbol{E}$, Control from same preparation; depolarization-evoked responses were unaffected by U73122. $F$, Mean amplitudes of the responses in the presence or absence of $\mathrm{U} 73122$ (mean $\pm \mathrm{SE} ;{ }^{*} p \cong 0.003$ ).

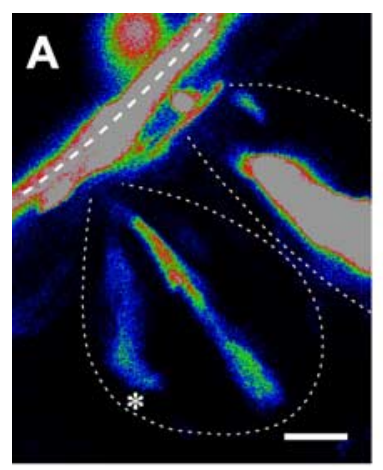

B
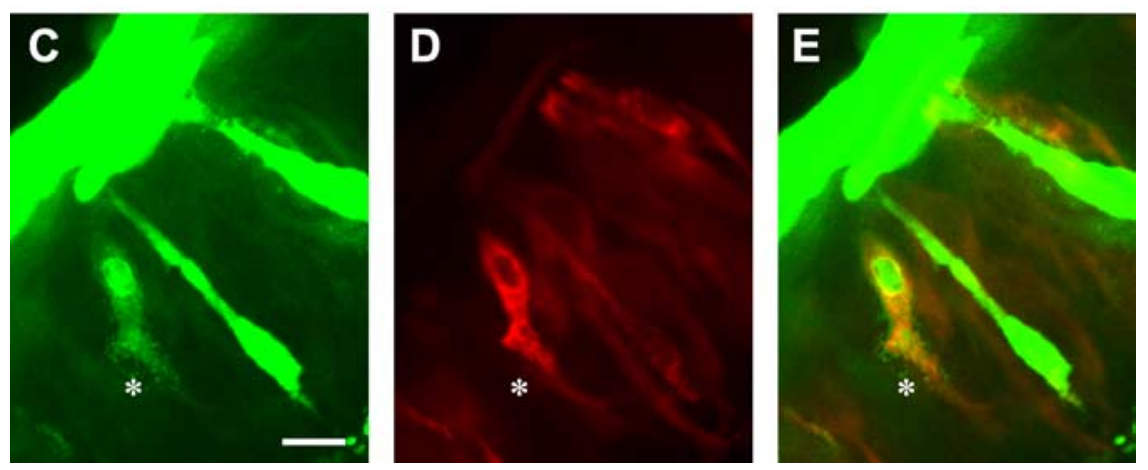

Figure 5. Umami-responsive cells express PLC $\beta 2$. A, Micrograph of a living slice preparation showing three cells filled with CaGD in two taste buds (dotted outlines). One of these cells (asterisk) responded to MPG plus IMP (next). The micrograph is pseudocolored to show CaGD fluorescence during live imaging (colors indicate pixel intensity mapping) (cf. Caicedo et al., 2000). A layer of CaGD fluorescent dye (dashed line) adheres to the surface epithelium and marks the mucosal boundary of the epithelium. $\boldsymbol{B}$, The cell marked by the asterisk in $\boldsymbol{A}$ responded to focal stimulation of the apical tip of the taste bud with $200 \mathrm{~mm}$ MPG plus $1 \mathrm{~mm}$ IMP. None of the other CaGD-filled cells in the taste buds responded to MPG plus IMP. $C-\boldsymbol{E}$, After immunostaining the preparation for PLC $\beta 2$, the same cell marked by the asterisk in $A$ was relocated. $C$, The CaGD signal (green) is still visible in the three taste cells after immunostaining. $\boldsymbol{D}, \mathrm{PLC} \beta 2$ immunoreactivity (red) is present in many taste cells, including the recorded cell (asterisk). $E$, Signals from the PLC $\beta 2$ immunostaining and CaGD channels are merged. Many taste cells other than the recorded cell contain either PLC $\beta 2$ or CaGD, but not both. Scale bars, $10 \mu \mathrm{m}$.

this anti-PLC $\beta 2$ antibody was confirmed with the use of tissue from PLC $\beta 2$ knock-out mice (Jiang et al., 1997). No fluorescent signals were evident in taste cells from the knock-out mice, processed in parallel with wild-type (WT) tissues (Kim et al., 2006). 


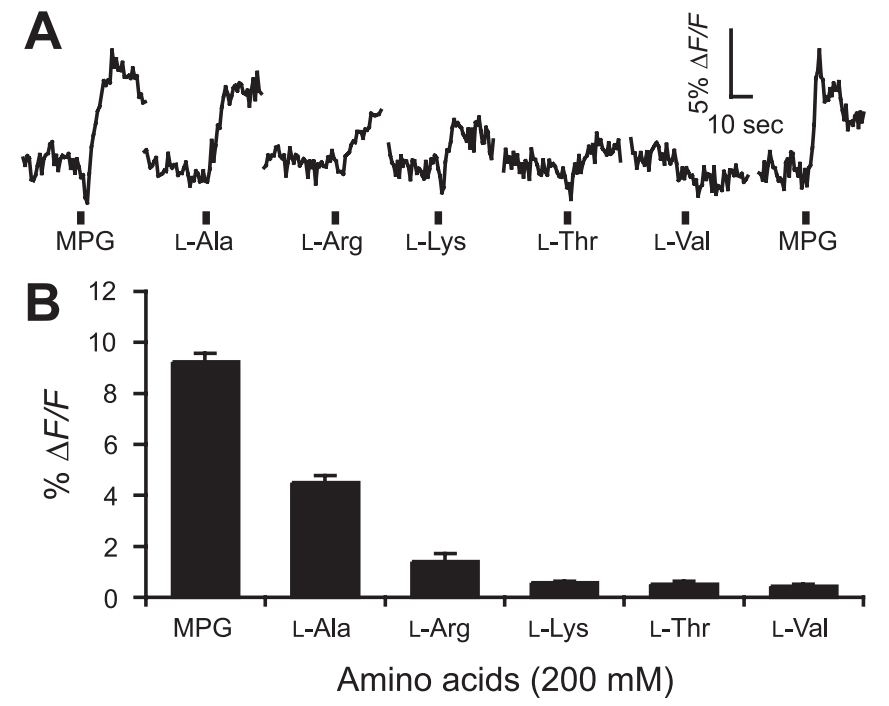

Figure 6. Taste cell responses evoked by focal application of MPG and other amino acids. $A$, Examples of responses from a taste cell after focal application of $200 \mathrm{mm:} \mathrm{MPG,} \mathrm{L-Ala,} \mathrm{L-Arg,}$ L-Lys, L-Thr, and L-Val, all containing $1 \mathrm{~mm} I M P$. B, Mean \pm SE amplitude of responses evoked by these stimuli ( $n=4$ cells).

We were unable to obtain $\mathrm{Ca}^{2+}$ responses to umami stimuli in taste cells from mutant mice lacking PLC $\beta 2$ tested in parallel experiments. Of 78 taste cells from PLC $\beta 2-\mathrm{KO}$ mice tested with glutamate plus IMP, none generated responses. This differs significantly from the incidence of umami-responsive cells in wildtype mice (i.e., 34 of 804 cells, see above; $p<0.05$, Fisher's exact test). Although it is possible that there are alterations in taste receptor cells from the $\mathrm{KO}$ mice other than just the absence of PLC $\beta 2$, this result is consistent with a central role of PLC $\beta 2$ in umami transduction.

Collectively, the above data confirm that the signals evoked by umami stimuli in mouse vallate taste cells represent PLCmediated release of stored $\mathrm{Ca}^{2+}$.

\section{Umami taste stimuli other than glutamate}

The T1R1+T1R3 heterodimer has been proposed to be the sole receptor underlying umami and amino acid responses in mice (Zhao et al., 2003). This receptor dimer, when transiently expressed in HEK293 cells, induces $\mathrm{Ca}^{2+}$ responses to glutamate plus IMP but, surprisingly, also to a broad range of amino acids not normally associated with umami taste (Nelson et al., 2002). We asked whether glutamate and other amino acids produced similar responses in native taste tissue of mice. We identified umami-responsive cells in circumvallate slices as described above and then focally stimulated these taste buds sequentially with five other L-amino acids identified to be effective at T1R1+T1R3, each at $200 \mathrm{~mm}$, in the presence of $1 \mathrm{~mm}$ IMP. As shown in Figure 6, $A$ and $B$, L-Ala induced a small but significant $\left[\mathrm{Ca}^{2+}\right]_{\mathrm{i}}$ increase in most glutamate-sensitive cells (MPG, $\Delta F / F=9.2 \pm 0.4 \%$; L-Ala, $4.5 \pm 0.3 \% ; n=4)$. Conversely, none of the other tested amino acids, L-Arg, L-Lys, L-Thr, or L-Val (each at $200 \mathrm{~mm}$ with 1 mM IMP), induced significant responses in glutamate-responsive circumvallate taste cells, nor did we did find responses to these amino acids (L-Arg, L-Lys, L-Thr, or L-Val) in glutamateinsensitive cells. The results suggest that the functional properties of native taste cells in the circumvallate papilla do not agree well with the response profiles reported from heterologous expression systems.

The glutamate analog L-AP-4 is an agonist for metabotropic
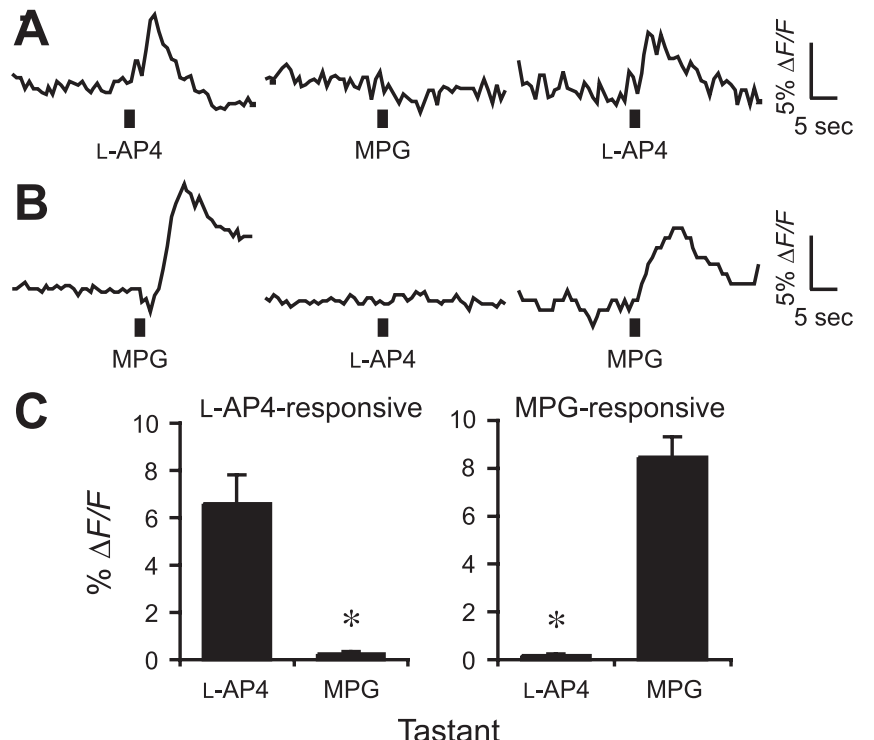

Figure 7. MPG-sensitive and L-AP-4-sensitive taste cells represent different cell populations. L-AP-4 (25 mM) and MPG ( $100 \mathrm{~mm}$ ) (each containing $1 \mathrm{~mm} \mathrm{IMP)}$ were applied sequentially to the apical tips of taste buds in the slice preparation. $A, 0$ ne taste cell responds to L-AP-4 but not to MPG (L-AP-4 responsive). $\boldsymbol{B}$, Another cell responds to MPG but not to L-AP-4 (MPGresponsive). C, Summary of responses to focal application of L-AP-4 and MPG for these two populations of taste cells (means $\pm \mathrm{SE} ;{ }^{*} p \cong 0.01$ for L-AP-4-responsive cells, $n=8$ cells; ${ }^{*} p<$ 0.001 for MPG-responsive cells, $n=5$ cells).

glutamate receptors, (specifically, mGluR4, mGluR6, mGluR7, and mGluR8). Furthermore, conditioned taste aversion experiments suggest that L-AP-4 produces a taste with marked similarity to glutamate in rats (Chaudhari et al., 1996; Stapleton et al., 1999) and mice (Nakashima et al., 2001). In transiently or stably expressing cell lines or Xenopus oocytes, L-AP-4 also activates truncated taste-mGluR4, truncated mGluR1, and T1R1+T1R3 dimers (Chaudhari et al., 2000; Nelson et al., 2002; San Gabriel et al., 2005). In combination, these results have suggested that L-AP-4 mimics the taste of MSG, at least in part by activating the same taste receptors as umami compounds (Delay et al., 2004). To test this interpretation directly, we focally applied glutamate and L-AP-4 sequentially to circumvallate taste buds. L-AP-4 (10 $\mathrm{mM}$ with $1 \mathrm{mM}$ IMP) evoked transient $\mathrm{Ca}^{2+}$ responses in some taste cells but not in those that responded to glutamate $(200 \mathrm{mM}$ with $1 \mathrm{mM}$ IMP) (L-AP-4, $\Delta F / F=6.8 \pm 1.8 \%$; MPG, $\Delta F / F=$ $0.2 \pm 0.2 \% ; n=8 ; p \cong 0.01$ ) (Fig. $7 A, C$ ). Conversely, glutamatesensitive cells did not respond to L-AP-4 (L-AP-4, $\Delta F / F=0.2 \pm$ $0.1 \%$; MPG, $\Delta F / F=8.5 \pm 0.9 \% ; n=5 ; p<0.001)($ Fig. $7 B, C)$. These data suggest that separate receptors, found on separate cells, generate our $\mathrm{Ca}^{2+}$ responses to MPG and L-AP-4. In cells that respond strongly to each agonist, we cannot rule out the possibility of subthreshold responses to the other agonist. Nevertheless, as in the case of amino acids (above), these results emphasize that responses to umami tastants in native taste tissues are highly heterogeneous and vary markedly from those described for the proposed umami receptors taken individually, tastemGluR4, truncated mGluR1, and T1R1+T1R3.

\section{Glutamate-induced responses in taste cells from T1R3 knock-out mice}

T1R3 has been proposed as an obligate member of the umami taste receptor dimer (Zhao et al., 2003). However, others have challenged those findings and concluded that multiple umami taste receptors exist (Damak et al., 2003). To test whether multi- 


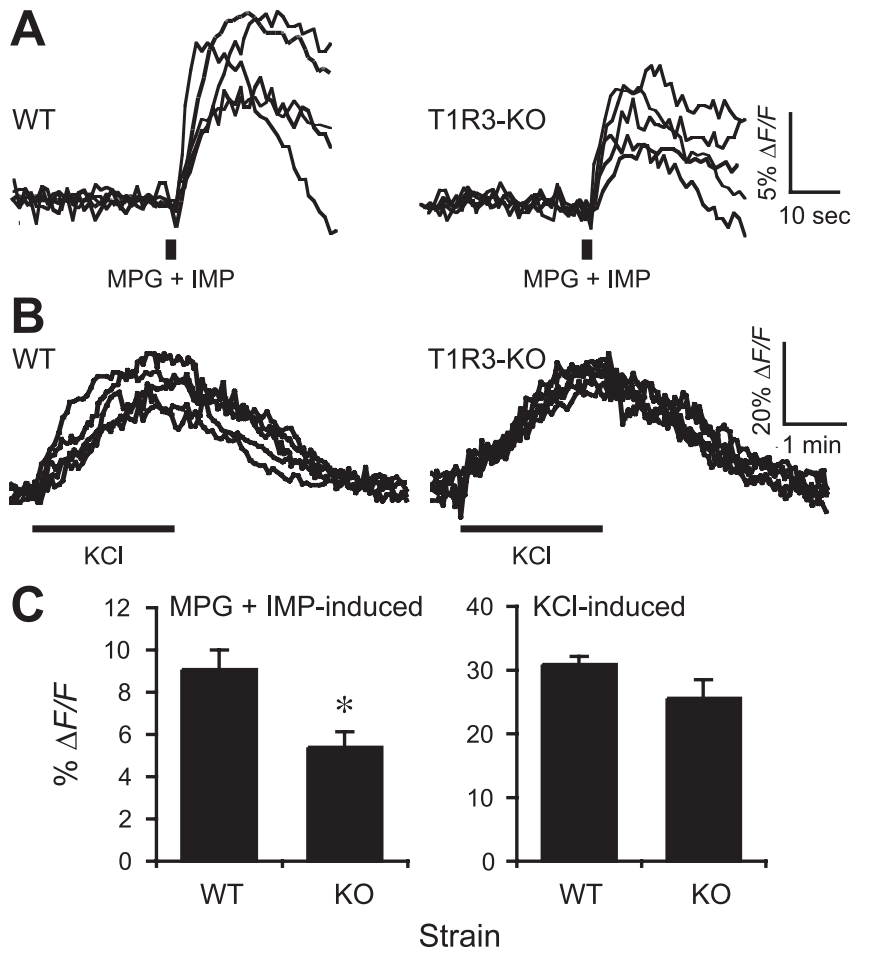

Figure 8. Umami stimulation evokes responses in circumvallate taste cells from mutant mice lacking T1R3. $A$, Superimposed recordings of responses from five different taste cells after MPG (500 mM) plus IMP (1 mM) stimulation. Recordings from WT mice are shown at left and from T1R3-null (T1R3-KO) mice at right. $\boldsymbol{B}$, Control responses to $\mathrm{KCl}$-depolarization recorded from taste cells from wild-type mice (left) and T1R3-null mice (right). C, Summary; mean amplitudes of responses in taste cells from wild-type and T1R3-null cells (mean $\pm \mathrm{SE} ;{ }^{*} p \cong 0.01$, $n=7$ or 6 for MPG-responsive cells in wild-type or T1R3 knock-out mice, respectively; $n=7$ or 5 for KCl-responsive cells in wild-type or T1R3 knock-out mice, respectively).

ple receptors might be involved in umami taste mechanisms, we compared glutamate-induced responses in circumvallate taste cells in lingual slices from WT mice and mutant mice lacking T1R3 (T1R3-null). MPG (plus IMP) induced $\mathrm{Ca}^{2+}$ responses in both WT and T1R3-null mice. However, in slices tested blindly and in parallel, the amplitude of glutamate responses in T1R3null taste cells were smaller than in WT taste cells (WT, $\Delta F / F=$ $9.1 \pm 0.9 \%, n=7$; T1R3-null, $5.4 \pm 0.7 \%, n=6 ; p \cong 0.01$ ) (Fig. $8)$. The incidence of umami-responsive taste cells was not noticeably different between the two genotypes. By way of control, there were no significant differences between the incidence or the amplitude of depolarization $(\mathrm{KCl})$-induced responses in WT and T1R3-null mice (WT, $\Delta F / F=30.9 \pm 1.3 \%, n=7$; T1R3-KO, $25.9 \pm 2.9 \%, n=5 ; p \cong 0.11)$.

\section{Discussion}

The aim of this study was to investigate umami taste responses in native taste cells in the mouse to compare results with the responses of cloned taste receptors expressed in heterologous cells (HEK293, CHO, and others). We used a preparation, lingual slices from vallate papilla, that allows one to apply tastants selectively to the apical chemosensory tips of taste cells while avoiding stimulating nontaste cells and basolateral regions of taste buds. We identified a small population $(\sim 5 \%)$ of taste cells in the circumvallate papillae that selectively respond to L-glutamate. This compares with our previous estimates, in the same preparation, of $28 \%$ cells that respond to bitter and $14 \%$ to sweet stimuli (Caicedo et al., 2002). The threshold concentration of L-glutamate needed to activate a $\mathrm{Ca}^{2+}$ response in taste cells was
$10 \mathrm{~mm}$. This is consistent with reports on behavioral analysis and sensory nerve recordings in mice (Yamamoto et al., 1991; Bachmanov et al., 2000; Inoue et al., 2004). As expected for umami taste, inosine 5'-monophosphate enhanced the L-glutamateevoked $\mathrm{Ca}^{2+}$ responses of taste cells.

Studying taste responses to L-glutamate is complicated by the necessity to apply a salt of glutamic acid yet avoid stimulating acid (sour) or salty taste mechanisms. Monosodium glutamate is conventionally used as the prototypic umami taste stimulus, but this itself introduces a possible confound, $\mathrm{Na}^{+}$taste (i.e., salty). We avoided these issues in the present study by using MPG as the taste stimulus. MPG elicits umami taste and has been used by others to investigate nerve responses to umami taste stimuli (Sako and Yamamoto, 1999; He et al., 2004). Although, as one might expect, $\mathrm{K}^{+}$is capable of depolarizing taste cells when bath applied to basolateral regions of the taste bud (Caicedo et al., 2000; Richter et al., 2004), focal application of K gluconate or $\mathrm{KCl}$ to the taste pore did not. Hence, we inferred that MPG only yielded responses to the anion moiety (i.e., glutamate) in taste cells. Parenthetically, in humans, potassium salts such as $\mathrm{KCl}$ elicit bitter-salty taste. One might anticipate that there would be a population of taste cells that are stimulated by focally applied $\mathrm{K}^{+}$salts. Such cells, if they exist in mouse circumvallate papillae, did not figure in the present report.

The magnitude of nucleotide potentiation in whole-nerve and single-fiber recordings varies considerably between the chorda tympani (CT) and glossopharyngeal (GL) nerves, even within a single species (Ninomiya et al., 1993, 2000). Gurmarin, a peptide that inhibits sweet taste in rodents, presumably by interaction with taste receptors, also inhibits umami signals preferentially in the CT (Yamamoto et al., 1991; Ninomiya et al., 1993, 2000; Sako and Yamamoto, 1999). Collectively, the nerve recording data suggest that responses to MSG differ significantly between the anterior (CT innervation) and posterior (GL innervation) lingual taste fields. Our findings demonstrate heterogeneity in the responses to various umami stimuli in individual taste cells, at least in the posterior tongue.

Our results suggest that glutamate-induced increases of $\left[\mathrm{Ca}^{2+}\right]_{\mathrm{i}}$ arise principally via mobilization from intracellular stores because responses were essentially unperturbed by depletion of extracellular $\mathrm{Ca}^{2+}$. Conversely, responses were abolished by pretreatment with thapsigargin or U73122, demonstrating the need for $\mathrm{Ca}^{2+}$ stores and the involvement of a phospholipase $\mathrm{C}$ (likely PLC $\beta 2$ ) in umami taste transduction. These results provide direct evidence of the existence of a functional umami receptor coupled to $\mathrm{Ca}^{2+}$ mobilization in taste receptor cells and explains the loss of behavioral and afferent responses to umami in PLC $\beta 2$ knock-out mice (Zhang et al., 2003). We note that neither thapsigargin nor U73122 totally eliminated $\mathrm{Ca}^{2+}$ responses evoked by umami stimuli. Whether this represents minor additional pathways remains unresolved.

Previously, it was reported that the heterodimer receptor T1R1+T1R3 is necessary and sufficient to elicit taste sensitivity to L-glutamate or to a number of other amino acids, as well as to L-AP-4 (Zhao et al., 2003). This interpretation was based on the observation that behavioral and neural responses to umami were absent in mice genetically lacking either T1R1 or T1R3. In contrast, an independently produced T1R3 knock-out mouse was reported to have reduced but still detectable responses to umami stimuli (Damak et al., 2003). Both of these reports used assays (behavioral and neural activity) that are one or more synapses downstream from the cells primarily affected by the genetic ablation: taste receptor cells. However, when we examined taste cells in T1R3-null mice, we found 
unequivocal evidence for umami-evoked $\mathrm{Ca}^{2+}$ responses that persist, albeit with a decreased amplitude. Our data strongly suggest that the T1R1+T1R3 dimer is not the sole umami taste receptor in the mouse. Furthermore, there are several discrepancies between the response profile of T1R1+T1R3 (in HEK293 cells) and of native taste cells. First, mouse T1R1+T1R3 is reported to be unresponsive to glutamate (even as high as $200 \mathrm{~mm}$ ) unless IMP is also present (Nelson et al., 2002). In contrast, we obtained measurable cellular responses to $30 \mathrm{~mm}$ glutamate alone, similar to the response of behaving animals. Second, although T1R1+T1R3 expressed in HEK293 cells responds to glutamate and a very broad range of amino acids (Nelson et al., 2002), our physiological studies in circumvallate slices show that glutamate-sensitive taste cells do not respond to L-Lys, L-Thr, and L-Val (all of which were effective on heterologously expressed T1R1+T1R3). Not surprisingly, many amino acids are thought to produce taste qualities distinct from umami, e.g., bitter for L-Val and sweet for L-Ala (Pritchard and Scott, 1982; Iwasaki et al., 1985).

In cDNA profiling experiments (Max et al., 2001) and in situ hybridization analyses (Kim et al., 2003), T1R1 and T1R3 were expressed independently of each other in substantial numbers of cells, especially in the vallate taste buds. The findings suggest that the T1R1+T1R3 pairing is not obligatory in native cells and that umami responses may stem from additional receptor types. Furthermore, although L-AP-4 and MSG are both umami stimuli, rats also easily discriminate between these tastants (Delay et al., 2004), indicating that some taste receptors may exist that are activated by one but not the other ligand, consistent with our findings (Fig. 7). Again, the implication is that umami responses may originate from more than a single type of receptor or receptor combination. Indeed, taste would not be unique in possessing such redundancy of receptors. Most mammalian sensory systems include more than a single receptor capable of responding to a given stimulus, whether these are multiple opsins (responding to a given wavelength of light), multiple odorant receptors (responding to a single odorant), or multiple receptors in peripheral nociceptors (responding to $\mathrm{H}^{+}$or ATP from tissue damage).

In summary, our results demonstrate that umami taste responses in native circumvallate taste cells are not concordant with the ligand specificities of any single proposed umami receptor: taste-mGluR4, T1R1+T1R3 dimers, or truncated mGluR1. We surmise that a full explanation of umami taste transduction may involve novel combinations of the receptors proposed to date and/or as-yet-undiscovered taste receptors (Ninomiya et al., 2000; Nakashima et al., 2001; Damak et al., 2003).

\section{References}

Abaffy T, Trubey KR, Chaudhari N (2003) Adenylyl cyclase expression and modulation of cAMP in rat taste cells. Am J Physiol Cell Physiol 284:C1420-C1428.

Bachmanov AA, Tordoff MG, Beauchamp GK (2000) Intake of umamitasting solutions by mice: a genetic analysis. J Nutr 130:935S-941S.

Bigiani A, Delay RJ, Chaudhari N, Kinnamon SC, Roper SD (1997) Responses to glutamate in rat taste cells. J Neurophysiol 77:3048-3059.

Bleasdale JE, Thakur NR, Gremban RS, Bundy GL, Fitzpatrick FA, Smith RJ, Bunting S (1990) Selective inhibition of receptor-coupled phospholipase C-dependent processes in human platelets and polymorphonuclear neutrophils. J Pharmacol Exp Ther 255:756-768.

Caicedo A, Jafri MS, Roper SD (2000) In situ $\mathrm{Ca}^{2+}$ imaging reveals neurotransmitter receptors for glutamate in taste receptor cells. J Neurosci 20:7978-7985.

Caicedo A, Kim K-N, Roper SD (2002) Individual mouse taste cells respond to multiple chemical stimuli. J Physiol (Lond) 544:501-509.

Chaudhari N, Yang H, Lamp C, Delay E, Cartford C, Than T, Roper S (1996) The taste of monosodium glutamate: membrane receptors in taste buds. J Neurosci 16:3817-3826.
Chaudhari N, Landin AM, Roper SD (2000) A metabotropic glutamate receptor variant functions as a taste receptor. Nat Neurosci 3:113-119.

Damak S, Rong M, Yasumatsu K, Kokrashvili Z, Varadarajan V, Zou S, Jiang P, Ninomiya Y, Margolskee RF (2003) Detection of sweet and umami taste in the absence of taste receptor T1r3. Science 301:850-853.

Delay ER, Sewczak GM, Stapleton JR, Roper SD (2004) Glutamate taste: discrimination between the tastes of glutamate agonists and monosodium glutamate in rats. Chem Senses 29:291-299.

Delwiche JF, Halpern BP, Desimone JA (1999) Anion size of sodium salts and simple taste reaction times. Physiol Behav 66:27-32.

Hayashi Y, Zviman MM, Brand JG, Teeter JH, Restrepo D (1996) Measurement of membrane potential and $\left[\mathrm{Ca}^{2+}\right]_{\mathrm{i}}$ in cell ensembles: application to the study of glutamate taste in mice. Biophys J 71:1057-1070.

He W, Yasumatsu K, Varadarajan V, Yamada A, Lem J, Ninomiya Y, Margolskee RF, Damak S (2004) Umami taste responses are mediated by $\alpha$-transducin and $\alpha$-gustducin. J Neurosci 24:7674-7680.

Helmchen F (2000) Calibration of fluorescent calcium indicators. In: Imaging neurons: a laboratory manual, Chap 32 (Yuste R, Lanni F, Konnerth A, eds). Cold Spring Harbor, NY: Cold Spring Harbor Laboratory.

Huang L, Shanker YG, Dubauskaite J, Zheng JZ, Yan W, Rosenzweig S, Spielman AI, Max M, Margolskee RF (1999) G $\gamma 13$ colocalizes with gustducin in taste receptor cells and mediates $\mathrm{IP}_{3}$ responses to bitter denatonium. Nat Neurosci 2:1055-1062.

Inoue M, Beauchamp GK, Bachmanov AA (2004) Gustatory neural responses to umami taste stimuli in C57BL/6ByJ and 129P3/J mice. Chem Senses 29:789-795.

Iwasaki K, Kasahara T, Sato M (1985) Gustatory effectiveness of amino acids in mice: behavioral and neurophysiological studies. Physiol Behav 34:531-542.

Jiang H, Kuang Y, Wu Y, Xie W, Simon MI, Wu D (1997) Roles of phospholipase $C \beta 2$ in chemoattractant-elicited responses. Proc Natl Acad Sci USA 94:7971-7975.

Kim J-W, Roberts C, Maruyama Y, Berg S, Roper SD, Chaudhari N (2006) Faithful expression of GFP from the PLC $\beta 2$ promoter in a functional class of taste receptor cells. Chem Senses, in press.

Kim M-R, Kusakabe Y, Miura H, Shindo Y, Ninomiya Y, Hino A (2003) Regional expression patterns of taste receptors and gustducin in the mouse tongue. Biochem Biophys Res Commun 312:500-506.

Kuninaka A (1960) Studies on taste of ribonucleic acid derivatives. J Agric Chem Soc Jpn 34:487-492.

Lin W, Kinnamon SC (1999) Physiological evidence for ionotropic and metabotropic glutamate receptors in rat taste cells. J Neurophysiol 82:2061-2069.

Lin W, Ogura T, Kinnamon SC (2003) Responses to di-sodium guanosine 5 '-monophosphate and monosodium L-glutamate in taste receptor cells of rat fungiform papillae. J Neurophysiol 89:1434-1439.

Lindemann B, Ogiwara Y, Ninomiya Y (2002) The discovery of umami. Chem Senses 27:843-844.

Max M, Shanker YG, Huang L, Rong M, Liu Z, Campagne F, Weinstein H, Damak S, Margolskee RF (2001) Tas1r3, encoding a new candidate taste receptor, is allelic to the sweet responsiveness locus Sac. Nat Genet 28:58-63.

Nakashima K, Katsukawa H, Sasamoto K, Ninomiya Y (2001) Behavioral taste similarities and differences among monosodium L-glutamate and glutamate receptor agonists in C57BL mice. J Nutr Sci Vitaminol (Tokyo) 47:161-166.

Nelson G, Chandrashekar J, Hoon MA, Feng L, Zhao G, Ryba NJ, Zuker CS (2002) An amino-acid taste receptor. Nature 416:199-202.

Ninomiya Y, Kajiura H, Mochizuki K (1993) Differential taste responses of mouse chorda tympani and glossopharyngeal nerves to sugars and amino acids. Neurosci Lett 163:197-200.

Ninomiya Y, Nakashima K, Fukuda A, Nishino H, Sugimura T, Hino A, Danilova V, Hellekant G (2000) Responses to umami substances in taste bud cells innervated by the chorda tympani and glossopharyngeal nerves. J Nutr 130:950S-953S.

Ogura T, Kinnamon SC (1999) $\mathrm{IP}_{3}$-independent release of $\mathrm{Ca}^{2+}$ from intracellular stores: a novel mechanism for transduction of bitter stimuli. J Neurophysiol 82:2657-2666.

Pritchard TC, Scott TR (1982) Amino acids as taste stimuli. Brain Res 253:81-92.

Richter TA, Caicedo A, Roper SD (2003) Sour taste stimuli evoke $\mathrm{Ca}^{2+}$ and $\mathrm{pH}$ responses in mouse taste cells. J Physiol (Lond) 547:475-483. 
Richter TA, Dvoryanchikov GA, Chaudhari N, Roper SD (2004) Acidsensitive two-pore domain potassium $\left(\mathrm{K}_{2} \mathrm{P}\right)$ channels in mouse taste buds. J Neurophysiol 92:1928-1936.

Rossler P, Kroner C, Freitag J, Noe J, Breer H (1998) Identification of a phospholipase C $\beta$ subtype in rat taste cells. Eur J Cell Biol 77:253-261.

Sako N, Yamamoto T (1999) Analyses of taste nerve responses with special reference to possible receptor mechanisms of umami taste in the rat. Neurosci Lett 261:109-112.

Sako N, Tokita K, Sugimura T, Yamamoto T (2003) Synergistic responses of the chorda tympani to mixtures of umami and sweet substances in rats. Chem Senses 28:261-266.

Salari H, Bramley A, Langlands J, Howard S, Chan-Yeung M, Chan H, Schellenberg R (1993) Effect of phospholipase C inhibitor U-73122 on antigen-induced airway smooth muscle contraction in guinea pigs. Am J Respir Cell Mol Biol 9:405-410.

San Gabriel AM, Uneyama H, Torii K, Yoshie S (2005) Functional characterization of a rat mGluR1 variant from vallate papillae. Chem Senses 30:A195.

Stapleton JR, Roper SD, Delay ER (1999) The taste of monosodium glutamate (MSG), L-aspartic acid, and N-methyl-D-aspartate (NMDA) in rats: are NMDA receptors involved in MSG taste? Chem Senses 24:449-457.
Thastrup O, Cullen PJ, Drobak BK, Hanley MR, Dawson AP (1990) Thapsigargin, a tumor promoter, discharges intracellular $\mathrm{Ca}^{2+}$ stores by specific inhibition of the endoplasmic reticulum $\mathrm{Ca}^{2+}$-ATPase. Proc Natl Acad Sci USA 87:2466-2470.

Thompson AK, Mostafapour SP, Denlinger LC, Bleasdale JE, Fisher SK (1991) The aminosteroid U-73122 inhibits muscarinic receptor sequestration and phosphoinositide hydrolysis in SK-N-SH neuroblastoma cells. J Biol Chem 266:23856-23862.

Yamamoto T, Matsuo R, Fujimoto Y, Fukunaga I, Miyasaka A, Imoto T (1991) Electrophysiological and behavioral studies on the taste of umami substances in the rat. Physiol Behav 49:919-925.

Yang H, Wanner IB, Roper SD, Chaudhari N (1999) An optimized method for in situ hybridization with signal amplification that allows the detection of rare mRNAs. J Histochem Cytochem 47:431-446.

Zhang Y, Hoon MA, Chandrashekar J, Mueller KL, Cook B, Wu D, Zuker CS Ryba NJ (2003) Coding of sweet, bitter, and umami tastes: different receptor cells sharing similar signaling pathways. Cell 112:293-301.

Zhao GQ, Zhang Y, Hoon MA, Chandrashekar J, Erlenbach I, Ryba NJ, Zuker CS (2003) The receptors for mammalian sweet and umami taste. Cell 115:255-266. 